\author{
KATALIN CZAKÓa) - TAMÁS DUSEK ${ }^{\text {b) }}$ - KRISZTIÁN KOPPÁNY(c) \\ - VERONIKA POREISZ ${ }^{\mathrm{d})}-$ ÉVA SZALKA $^{\mathrm{e}}$
}

\title{
Economies of Scale in Local Communal Services in Hungary*
}

\begin{abstract}
Knowledge of whether, and over what range of output, there are economies or diseconomies of scale in providing local communal services is an important question from a theoretical, practical and regional political point of view. The theoretical side of the question is connected to the primary research regarding the optimal city size. If an optimal city size can actually be established, then a valid policy argument can be made for fostering its approximation. However, theoretical considerations are sometimes based on those types of assumptions, which are often not valid in reality. Therefore, empirical investigations are essential in this research area.

After a short theoretical overview, the paper initially gives a general outline of previous controversial empirical evidence on economies of scale regarding community size and the provision of local communal services. In the second part, the empirical findings are presented; these concern economies of scale in local communal services based on a large and detailed database, which consist of almost 300 Hungarian settlements. During the research, a number of methodological questions have occurred. For example, there are several solutions for the organisational structure providing local services, from a large holding to the smaller individual companies. Considering this and some other issues, the main results suggest that on a community level, there are moderate economies of scale in water supply, sewage disposal and district heating and a moderate diseconomy of scale in refuse collection until 5 thousand inhabitants. Above this level there is no connection between the settlement size and the average cost of services. The results are mainly consistent with the previous findings: there are economies of scale under a certain threshold, but after this, unit cost reduction is not feasible. This threshold can be different in the different types of services.
\end{abstract}

Keywords: economies of scale, local communal services, Hungary.

a) Széchenyi István University, Györ, Hungary, 9026, Egyetem tér 1. E-mail: ckatalin@sze.hu

b) Széchenyi István University, Györ, Hungary, 9026, Egyetem tér 1. dusekt@sze.hu

c) Széchenyi István University, Györ, Hungary, 9026, Egyetem tér 1. E-mail: koppanyk@sz.hu

d) Széchenyi István University, Györ, Hungary, 9026, Egyetem tér 1. E-mail: poreisz@sze.hu

e) Széchenyi István University, Győr, Hungary, 9026, Egyetem tér 1. E-mail: szeva@sze.hu

* The research was supported by TÁMOP-4.2.2.A-11/1/KONV-2012-0010: Regional Vehicle Industrial District as a New Direction and Tool of Area Development ("A Győri Jármüipari Körzet, mint a térségi fejlesztés új iránya és eszköze") project. 


\section{Introduction}

Knowledge of whether, and over what range of output, there are economies or diseconomies of scale in providing local communal services is an important question from theoretical, practical and regional political point of view. The theoretical side of the question is connected to the primary research concerning the optimal city size. If optimal city size can actually be established, then a valid policy argument can be made for fostering its approximation. However, theoretical considerations are sometimes based on those types of assumptions, which are often not valid in reality. Therefore, empirical investigations are essential in this research area.

This paper will be organised as follows. After a short theoretical overview, it gives a general outline about the previous controversial empirical evidences on economies of scale in the community and providing local communal services. In the second part, we present our empirical findings concerning to economies of scale in local communal services based on a large and detailed database which consist of almost 300 Hungarian settlements. The main results suggest that on a community level there are moderated economies of scale in water supply, sewage disposal and district heating and moderated diseconomies of scale in refuse collection until five thousand inhabitants. Above this level, there is no connection between the settlement size and the average cost of services. This result is mainly consistent with the previous findings: there are economies of scale under a certain threshold, but after this, unit cost reduction is not feasible. This threshold can be different in the different types of services.

\section{Theoretical background}

Classic economies of scale relate to the effect on average costs of production of different rates of output. Economies of scale or scale economies exist if increased output goes hand in hand with lower average costs. The sources of economies of scale can be manifold, most of them can be classified either as technical or organisational reasons: mechanization, specialization, division of labour, vertical and horizontal integration and so on.

Economies of scale is a simple concept on a conceptual level but its measurement is very difficult in practice, where the measurement of "output" and "cost" can be highly complicated. The simplest case, the homogenous quality of only one output is extraordinarily rare in reality. The vast majority of the controversial results of the empirical investigations in a wide range of various activities (industrial activities and services) can be traced back to the definitional and measurement problems of output and costs and/or to the treatment of quality considerations. Measuring the output of a school, hospital or public administration is extremely difficult. Cost of production can also be very different, not only due to problems of non-monetary costs elements, but when taking into consideration the costs that arise for the consumer (for example transportation cost, quality considerations), not just from the side of the producer. Analysis and comparison of local communal services has to cope with other difficulties besides the pure qualitative problems: the significant institutional variation between local government administration in the same country, different population densities, and geographical environment and 
settlement structure variations between the same size settlements. However, quantitative analysis must choose some form of measurement.

There is an important practical difference between the private enterprises of industries and services and the communal services of the public sector. As a result of competition, there is a permanent pressure on private enterprises to take advantage of the potential economies of scale and to avoid uneconomic solutions. This is one motivation for mergers and disintegration or outsourcing. Public communal enterprises have three constraints to achieving the optimal organisational size: regulation, the fixed size of settlements and the fixed locality as an outer condition. The third constraint is the most severe. Regulation can also facilitate the utilization of economies of scale. Joint services are a feasible opportunity in many cases, which can manage at least partly the constraints of settlement size.

Theoretically, city size may lead to economies and diseconomies of scales. Larger city size may enable the spreading of overhead costs over a large number of people, reducing unit costs and thereby achieving economies of scale. Besides these factors, larger cities have a more varied public sector, with units of services beyond the optimum scale. However, among smaller local government units, the competition becomes more intensive, which leads to greater efficiency and lower costs. Empirical investigations are necessary to discover the real connections between city size and average cost of services.

\section{Previous studies}

There are few empirical studies about the economies of scale in local communal services and the cost of local administration in Hungary, despite that the question is often mentioned theoretically and in political discussions, both on settlement level and higher-level reorganisation of spatial structures. On a settlement level, the fragmented structure with several very small autonomous settlements is criticized as inefficient (Verebélyi 1993). Empirical investigations of local public services, such as nursery, elementary school, and cost of general administration suggest that the average cost of various activities is slightly different between the various size categories of settlements, but the difference cannot be interpreted as an economy of scale. For example, the lowest average cost of administration can be detected in large villages (population above 5000 inhabitants); both smaller villages and larger cities have higher average costs, but the difference is very small (Fekete et al. 2002, p. 51-57.). Other papers in this publication deal with Poland, Slovakia and Bulgaria and have found slight economies of scale in administration costs (Swianiewicz 2002).

There are economies of scale in solid waste and sewage-water management (Hermann et al. 1998, Kerekes 2002). However, the increasing transportation cost was not taken into consideration in these results. Bálint Koós and Mihály Lados conducted research about the size and number of settlements. According to their results, the number of settlements is not too large; however, the large number of various tasks of the settlement and the lack of joint services between settlements is a real problem (Koós-Lados 2008). György Budaházy's (2013) analysis regarding economies of scale in land registry offices was conducted on a county level. His results show that there is a linear connection between the size of the county and the cost of the land registry office: simply, a twice the size county has twice the costs. 
The number and time horizon of empirical investigations in various other countries is, of course, enormous and cannot be reviewed in a short paper. It is worth stressing the contradictory character of various results. General statements without any empirical evidence are quite common in reports of various advisory boards. Size of a school district in USA is a classic example. School district consolidation in USA from the 1930s was motivated by the belief that economies of scale existed in this service. "Although the validity of this assumption was never tested, 'Bigger is Cheaper' became the mantra of the profession as future generations of administrators were taught to believe" (Robertson 2007, p. 620). However, the growing empirical literature suggests that administrative efficiencies can be increased by merging small districts into larger ones, but only within limits, which lies somewhere between 500 and 1000 students. When this threshold is crossed, it will often result in decreased administrative efficiencies (Hanley 2007).

Local government reforms in many countries focus on compulsory council consolidation, amalgamation of smaller administrative units into larger ones under the slogan of efficiency, and enhancing the planning and administrative capacities. This is true, for example, for Australia (Dollery et al. 2010), Greece (Hlepas 2010), Denmark (Vrangbaek 2010), Germany (Wollmann 2010) and Macedonia (Kreci-Imeri 2010). However, empirical proofs of the slogans are rare and mixed. In "Moderning Local Government" by the Committee for Economic Development in USA the following quote is telling: "The most pressing problem of local government in metropolitan areas may be stated quite simply. The bewildering multiplicity of small, piecemeal, duplicative, overlapping local jurisdictions cannot cope with the staggering difficulties encountered in managing modern urban affairs. The fiscal effects of duplicative suburban separatism create great difficulty in the provision of costly central city services benefitting the whole urbanized area. If local governments are to function effectively in metropolitan areas, they must have sufficient size and authority to plan, administer, and provide significant financial support for solutions to area-wide problems" (cited by Hutcheson-Prather 1979, p. 166). According to this, increasing the size of jurisdictions would supposedly allow economies of scale to accrue to local governments and enhance the efficiency of service delivery systems. However, empirical evidence shows little sign of economies of scale. A pioneering work by Hirsch, using data from 149 local governments around St Louis and in Massachusetts, found that growth and consolidation appear to have little, if any, significant effect on per capita expenditures for fire protection, police protection, refuse collection, and other similar services. These make up the vast majority $(80-85 \%)$ of all city expenditures. Consolidation of water and sewage services, accounting for approximately $10 \%$ of total expenditure, leads to a decline in per capita expenditures until a very large scale is reached. After this point, there are no further economies of scale (Hirsch 1959).

Gabler's paper analysed the connection between settlement size and average cost for several functions, such as highways, police, fire service, sewerage and sanitation, parks and recreation, general expenditures. In most cases the per capita expenditures are larger in larger towns, that is, diseconomies of scale exist, except for highways (Gabler 1971). Hutcheson and Prater (1979) show that $1 \%$ increase of population goes hand in hand with $1.2 \%$ increase in the size of administration. Andrews and Boyne (2009) have opposite results in their paper about English local authorities: the relationship between population size and back office cost is negative; economies of scale might be achieved by 
amalgamating smaller councils into larger units. Knapp's paper deals with the economies of scale of crematoriums in England. This analysis is particularly interesting, because the cost structure and the output can be accurately measured. Economies of scale exist until 3000 cremations, above this level there are diseconomies of scale due to the more complex coordination (Knapp 1982).

The interpretations and comparisons of results are not easy, because almost every local government service unit has a variety of quality dimensions. "In assessing the influence of population size on urban public sectors, however, it is necessary to note that the concepts of diseconomies and economies of scale assume a constant level of service quality" (Gabler 1971, p. 131). For example, increasing the size of the schools leads to loss of personalisation, lower motivation of teachers, parents and students. Growing service units means larger distances from the consumer and greater transportation costs. In residential refuse collection, the frequency and the manner of collection, the care and reliability of the removal services, cleanliness, quietness and courtesy of collection crew are important factors. Provision of water and sewer service is influenced by natural conditions.

Almost every service is influenced by the population density. Some writers emphasize the spatially explicit economies of density instead of spatial economies of scale (Walls et al. 2005, Nauges-van der Berg 2008). Drew et al. (2012) point out that when areas are decomposed into subgroups (in the Australian research area) on the basis of density, the evidence of scale economies largely disappears. Buettner et al. (2004) show that on a regional level, there are no connections between population density, the size of population and public expenditure. "Per capita expenditures tend to be almost constant in response to changes in the size of population, indicating that most of the goods provided by the state governments tend to be quasi-private goods" (Buettner et al. 2004, p. 510). According to Holcombe and Williams (2009), municipal government expenditures are characterised by constant returns to scale (examining 487 municipalities above 50 thousand inhabitants in the USA), but population density and various demographic factors influence the level of expenditure of local governments. Ladd argues that a U-shaped relationship exists between population density and the cost of providing public services: average cost is highest in sparsely populated areas and at higher density. Ladd's data set consisted of 247 large counties in the USA, 59 percent of the population of the USA (Ladd 1992).

In a recent survey, Saal et al. summarised the results of more than 20 examinations on the efficiency of the water industry. Typically, there are economies of scale up to certain output level, and diseconomies of scale after the optimal point. However, the optimal is situation-dependent and differs largely from country to country. (Saal et al. 2013)

\section{Database of the analysis}

The analysis intended to build a temporal database with company-level business data in the following areas of communal services: water supply, sewage disposal, refuse collection, district heating, general communal services, property and real estate management. In building the database, several practical problems were confronted: correct identification of activities, frequent temporal changes in organisational structure, mixed and holding structure of companies. Each company was checked individually. Due to the temporal matching problems, the database is static. Each year from 2002 to 2011 has its 
unique classification. Because of the abundance of data and the similarity of the results, only the results of the latest year, 2011 are shown.

The division according to sectors and settlement size can be seen in Table 1 and Table 2. The only city above 250 thousand inhabitants is Budapest, which is an outlier with its 1.7 million inhabitants. Every large city (above 50 thousand inhabitants) is represented in the database as well as the majority of medium sized settlements. In smaller settlements categories, the rate of investigated settlements is smaller. Mixed services category means integrated companies with every local public service. There is duplication in the table, because some companies provide more than one service, typically water supply and sewage disposal.

Table 1

The number of settlements and companies

\begin{tabular}{|c|c|c|c|c|c|c|}
\hline $\begin{array}{l}\text { Size of the } \\
\text { settlement } \\
\text { (thousand } \\
\text { inhabitants) }\end{array}$ & $\begin{array}{c}\text { Number of } \\
\text { settlements } \\
\text { in the analysis }\end{array}$ & $\begin{array}{l}\text { District } \\
\text { heating }\end{array}$ & $\begin{array}{l}\text { Water } \\
\text { supply }\end{array}$ & $\begin{array}{l}\text { Sewage } \\
\text { disposal }\end{array}$ & $\begin{array}{l}\text { Refuse } \\
\text { collection }\end{array}$ & $\begin{array}{c}\text { Mixed services } \\
\text { (holding } \\
\text { structure) }\end{array}$ \\
\hline $250.0-$ & 1 & 5 & 2 & 5 & 1 & 1 \\
\hline $100.0-250.0$ & 8 & 10 & 13 & 13 & 15 & 5 \\
\hline $50.0-100.0$ & 12 & 7 & 13 & 13 & 14 & 3 \\
\hline $30.0-50.0$ & 21 & 7 & 20 & 12 & 13 & 5 \\
\hline $20.0-30.0$ & 18 & 6 & 12 & 8 & 11 & 3 \\
\hline $15.0-20.0$ & 24 & 10 & 21 & 14 & 16 & 8 \\
\hline $10.0-15.0$ & 35 & 12 & 20 & 14 & 15 & 3 \\
\hline $7.5-10.0$ & 27 & 0 & 25 & 16 & 7 & 3 \\
\hline $5.0-\quad 7.5$ & 32 & 3 & 20 & 17 & 8 & 5 \\
\hline $2.5-\quad 5.0$ & 55 & 1 & 34 & 22 & 10 & 5 \\
\hline$-\quad 2.5$ & 60 & 1 & 24 & 26 & 10 & 0 \\
\hline Total & 293 & 62 & 204 & 160 & 120 & 41 \\
\hline
\end{tabular}

The number of settlements

\begin{tabular}{c|c|c}
\hline $\begin{array}{c}\text { Size of the settlement } \\
\text { (thousand inhabitants) }\end{array}$ & $\begin{array}{c}\text { Number of settlements } \\
\text { in Hungary }\end{array}$ & $\begin{array}{c}\text { Number of settlements in } \\
\text { the analysis }\end{array}$ \\
\hline $250.0-$ & 1 & 1 \\
$100.0-250.0$ & 8 & 8 \\
$50.0-100.0$ & 12 & 12 \\
$30.0-50.0$ & 21 & 21 \\
$20.0-30.0$ & 21 & 18 \\
$15.0-20.0$ & 29 & 24 \\
$10.0-15.0$ & 52 & 35 \\
$7.5-10.0$ & 46 & 27 \\
$5.0-7.5$ & 100 & 32 \\
$2.5-5.0$ & 332 & 55 \\
-2.5 & 2,535 & 60 \\
\hline
\end{tabular}


Analysis

Economies of scale could be best analysed according to the average cost, namely the ratio of total cost and the output. Yet for the output, data is not available in real terms, only monetary data. Therefore, six proxies are used. These can be seen in Table 3. Four of them use the number of inhabitants as denominator. Population is not the best measure for four reasons: settlement borders are sometimes arbitrary, some services (water and sewage) serve several neighbouring settlements, the number of inhabitants and the number of served persons can be different, and the composition of inhabitants (age structure, income level, unemployment rate and other socio-economic factors) can also vary. However, without other data, population figures provide the best available solution. The other ten indicators use only company level data (number of employees and various fiscal indicators). The first indicator can be treated as the primary index of economies of scale: a smaller value indicates more cost efficient activities, although, as mentioned previously, quality and other differences are disregarded. Other indicators are supplements for the broader view and rather show the effect of size on organisational structure and labour/capital ratio.

Table 3

Proxies for economies of scale

\begin{tabular}{c|l}
\hline Number of proxy & Short description of indicator \\
\hline 1 (basic indicator) & Revenues/production costs \\
2 (secondary indicator) & Production costs/inhabitants \\
3 (secondary indicator) & Production costs/employees \\
4 (secondary indicator) & Revenues/inhabitants \\
5 (secondary indicator) & Revenues/employees \\
6 (secondary indicator) & Employees/inhabitants
\end{tabular}

The calculations can be seen in Tables 4-9 for all services together and for each service separately. The general results can be broadly summarised: there is no systematic connection between settlement size and the average cost of the various services. Only the largest settlement (Budapest with 1.7 million inhabitants) and the settlements under five thousand inhabitant show minor economies or diseconomies of scale. Budapest has the smallest average costs in water supply and sewage disposal. The smallest settlements have the lowest average costs in refuse collection, but highest in district heating. These results can be readily explained by the fact that refuse collection is not capital intensive; however central heating and water supply and sewage disposal are capital intensive activities with large fix costs. Large fix costs are the explanation for the absence of district heating in the vast majority of smaller settlements. However, between five thousand and 250 thousand inhabitants there are no clear tendencies in of either economies of scale or diseconomies of scale. 
Indicators for all services (continued)

Table 4

\begin{tabular}{c|c|c|c|c|r|r}
\hline \multirow{2}{*}{ Settlement size } & \multicolumn{7}{|c}{ Number of indicators (see Table 3) } \\
\cline { 2 - 6 } & 1 & 2 & 3 & 4 & 5 & 6 \\
\hline $250.0-$ & 0.88 & 9.06 & 32.08 & 10.30 & 36.47 & 0.28 \\
$100.0-250.0$ & 0.97 & 21.15 & 15.80 & 21.83 & 16.32 & 1.34 \\
$50.0-100.0$ & 0.96 & 51.60 & 18.40 & 53.80 & 19.19 & 2.80 \\
$30.0-50.0$ & 0.96 & 28.58 & 10.36 & 29.76 & 10.78 & 2.76 \\
$20.0-30.0$ & 0.98 & 53.73 & 9.92 & 54.77 & 10.11 & 5.41 \\
$15.0-20.0$ & 0.99 & 40.54 & 12.02 & 40.85 & 12.11 & 3.37 \\
$10.0-15.0$ & 0.95 & 25.00 & 10.30 & 26.24 & 10.81 & 2.43 \\
$7.5-10.0$ & 0.96 & 22.49 & 7.85 & 23.49 & 8.19 & 2.87 \\
$5.0-7.5$ & 0.94 & 32.42 & 10.50 & 34.43 & 11.15 & 3.09 \\
$2.5-5.0$ & 0.99 & 31.36 & 7.74 & 31.62 & 7.81 & 4.05 \\
-2.5 & 0.87 & 42.59 & 11.62 & 49.08 & 13.39 & 3.67 \\
\hline Total & 0.94 & 17.48 & 16.62 & 18.67 & 17.75 & 1.05
\end{tabular}

Source: Own calculation based on company level data.

Table 5

Indicators for district heating

\begin{tabular}{c|c|c|c|c|c|c}
\hline \multirow{2}{*}{ Settlement size } & \multicolumn{7}{|c}{ Number of indicators (see Table 3) } \\
\cline { 2 - 7 } & 1 & 2 & 3 & 4 & 5 & 6 \\
\hline $250.0-$ & 0.97 & 13.62 & 113.02 & 13.98 & 115.98 & 0.12 \\
$100.0-250.0$ & 1.05 & 44.94 & 30.98 & 42.95 & 29.61 & 1.45 \\
$50.0-100.0$ & 0.98 & 155.09 & 60.29 & 158.94 & 61.79 & 2.57 \\
$30.0-50.0$ & 1.00 & 30.30 & 19.52 & 30.31 & 19.52 & 1.55 \\
$20.0-30.0$ & 1.07 & 55.64 & 18.11 & 52.07 & 16.94 & 3.07 \\
$15.0-20.0$ & 1.03 & 79.81 & 30.12 & 77.64 & 29.30 & 2.65 \\
$10.0-15.0$ & 1.05 & 27.42 & 32.17 & 26.14 & 30.67 & 0.85 \\
$7.5-10.0$ & 0.97 & 28.60 & 11.52 & 29.59 & 11.92 & 2.48 \\
$5.0-7.5$ & 1.24 & 39.43 & 14.00 & 31.71 & 11.26 & 2.82 \\
$2.5-5.0$ & 1.36 & 31.85 & 9.74 & 23.44 & 7.16 & 3.27 \\
\hline Total & 1.00 & 25.27 & 49.64 & 25.35 & 49.79 & 0.51
\end{tabular}

Source: Own calculation based on company level data. 
Indicators for water supply

\begin{tabular}{c|c|c|c|c|r|r}
\hline \multirow{2}{*}{ Settlement size } & \multicolumn{7}{|c}{ Number of indicators (see Table 3) } \\
\cline { 2 - 7 } & 1 & 2 & 3 & 4 & 5 & 6 \\
\hline $250.0-$ & 0.85 & 6.93 & 18.58 & 8.17 & 21.89 & 0.37 \\
$100.0-250.0$ & 0.93 & 22.61 & 11.46 & 24.26 & 12.30 & 1.97 \\
$50.0-100.0$ & 0.97 & 57.34 & 11.23 & 59.36 & 11.62 & 5.11 \\
$30.0-50.0$ & 0.96 & 39.68 & 9.48 & 41.36 & 9.88 & 4.19 \\
$20.0-30.0$ & 0.98 & 86.49 & 9.90 & 88.17 & 10.09 & 8.73 \\
$15.0-20.0$ & 0.96 & 42.29 & 9.24 & 43.85 & 9.58 & 4.58 \\
$10.0-15.0$ & 0.92 & 26.57 & 8.56 & 28.93 & 9.32 & 3.11 \\
$7.5-10.0$ & 0.95 & 24.00 & 7.04 & 25.23 & 7.40 & 3.41 \\
$5.0-7.5$ & 0.96 & 27.48 & 7.98 & 28.51 & 8.28 & 3.44 \\
$2.5-5.0$ & 0.99 & 25.10 & 6.09 & 25.27 & 6.13 & 4.12 \\
-2.5 & 1.09 & 29.16 & 8.48 & 26.73 & 7.77 & 3.44 \\
\hline Total & 0.94 & 24.43 & 10.66 & 25.91 & 11.31 & 2.29
\end{tabular}

Source: Own calculation based on company level data.

Table 7

Indicators for sewage disposal

\begin{tabular}{c|c|r|r|r|r|r}
\hline \multirow{2}{*}{ Settlement size } & \multicolumn{7}{|c}{ Number of indicators (see Table 3) } \\
\cline { 2 - 7 } & 1 & 2 & \multicolumn{1}{c}{3} & \multicolumn{1}{c}{5} & \multicolumn{1}{c}{5} \\
\hline $250.0-$ & 0.70 & 3.30 & 23.52 & 4.72 & 33.67 & 0.14 \\
$100.0-250.0$ & 0.93 & 18.12 & 10.67 & 19.51 & 11.49 & 1.70 \\
$50.0-100.0$ & 0.95 & 50.15 & 11.55 & 52.71 & 12.14 & 4.34 \\
$30.0-50.0$ & 0.95 & 52.75 & 9.75 & 55.47 & 10.26 & 5.41 \\
$20.0-30.0$ & 0.98 & 107.31 & 10.73 & 109.11 & 10.91 & 10.00 \\
$15.0-20.0$ & 0.98 & 41.39 & 7.43 & 42.08 & 7.56 & 5.57 \\
$10.0-15.0$ & 0.93 & 31.22 & 8.67 & 33.60 & 9.34 & 3.60 \\
$7.5-10.0$ & 0.92 & 28.84 & 9.47 & 31.29 & 10.28 & 3.05 \\
$5.0-7.5$ & 0.98 & 36.54 & 14.79 & 37.39 & 15.13 & 2.47 \\
$2.5-5.0$ & 1.03 & 19.41 & 8.22 & 18.78 & 7.95 & 2.36 \\
-2.5 & 1.05 & 29.96 & 9.66 & 28.52 & 9.19 & 3.10 \\
\hline Total & 0.90 & 13.95 & 11.32 & 15.47 & 12.56 & 1.23
\end{tabular}

Source: Own calculation based on company level data. 
Indicators for refuse collection

\begin{tabular}{c|c|c|c|c|r|r}
\hline \multirow{2}{*}{ Settlement size } & \multicolumn{7}{|c}{ Number of indicators (see Table 3) } \\
\cline { 2 - 7 } & 1 & 2 & 3 & 4 & 5 & 6 \\
\hline $250,0-$ & 0.83 & 19.19 & 11.72 & 23.13 & 14.13 & 1.64 \\
$100,0-250,0$ & 0.92 & 16.66 & 11.74 & 18.16 & 12.80 & 1.42 \\
$50,0-100,0$ & 0.90 & 18.40 & 12.67 & 20.52 & 14.13 & 1.45 \\
$30,0-50,0$ & 0.84 & 19.36 & 8.48 & 23.00 & 10.08 & 2.28 \\
$20,0-30,0$ & 0.91 & 30.11 & 7.80 & 33.13 & 8.58 & 3.86 \\
$15,0-20,0$ & 0.93 & 26.53 & 9.20 & 28.57 & 9.91 & 2.88 \\
$10,0-15,0$ & 0.93 & 27.77 & 8.46 & 29.71 & 9.06 & 3.28 \\
$7,5-10,0$ & 0.97 & 25.67 & 9.75 & 26.45 & 10.05 & 2.63 \\
$5,0-7,5$ & 0.84 & 42.84 & 12.44 & 51.05 & 14.83 & 3.44 \\
$2,5-5,0$ & 0.94 & 76.39 & 9.97 & 80.87 & 10.56 & 7.66 \\
$-2,5$ & 0.70 & 119.69 & 16.22 & 171.71 & 23.27 & 7.38 \\
\hline Total & 0.88 & 20.12 & 10.81 & 22.85 & 12.28 & 1.86
\end{tabular}

Source: Own calculation based on company level data.

Table 9

Indicators for mixed services (holding structure)

\begin{tabular}{c|c|c|c|c|c|c}
\hline \multirow{2}{*}{ Settlement size } & \multicolumn{7}{|c}{ Number of indicators (see Table 3) } \\
\cline { 2 - 6 } & 1 & 2 & 3 & 4 & 5 & 6 \\
\hline $250.0-$ & 0.83 & 19.19 & 11.72 & 23.13 & 14.13 & 1.64 \\
$100.0-250.0$ & 0.95 & 33.25 & 12.34 & 35.04 & 13.00 & 2.69 \\
$50.0-100.0$ & 0.87 & 30.41 & 11.09 & 34.84 & 12.71 & 2.74 \\
$30.0-50.0$ & 1.01 & 25.58 & 10.01 & 25.27 & 9.89 & 2.56 \\
$20.0-30.0$ & 0.88 & 43.07 & 6.19 & 48.89 & 7.03 & 6.96 \\
$15.0-20.0$ & 1.08 & 28.55 & 7.06 & 26.42 & 6.53 & 4.05 \\
$10.0-15.0$ & 1.08 & 51.40 & 8.61 & 47.55 & 7.97 & 5.97 \\
$7.5-10.0$ & 1.43 & 19.05 & 4.29 & 13.30 & 2.99 & 4.44 \\
$5.0-7.5$ & 1.02 & 28.30 & 5.61 & 27.86 & 5.52 & 5.04 \\
$2.5-5.0$ & 0.95 & 20.52 & 7.72 & 21.64 & 8.14 & 2.66 \\
\hline Total & 0.90 & 25.19 & 10.64 & 27.96 & 11.81 & 2.37
\end{tabular}

Source: Own calculation based on company level data.

\section{Summary and further research}

In the paper, an overview was taken of the connection between settlement size and the average cost of communal services, referring also to the perennial question of optimal settlement size. The results suggest that there is no optimal settlement size from the point of view of communal services. Only the small settlements (under approximately five thousand inhabitants) have some minor cost disadvantages in activities with high fixed 
capital costs (water supply, sewage disposal, central heating). The next stage of the research will include some of those factors that were mentioned in the broader introduction: the cost structure, the effect of settlement structure and population density, the number of served individuals and furthermore some demographic and socio-economic factors, which have potential influence on the economic status of communal service companies. The explanation of the significant differences in secondary indicators (such as revenues/inhabitants, assets/employees) will also be examined.

\section{REFERENCES}

Andrews, R. - Boyne, G. A. (2009): Size, structure and administrative overheads: an empirical analysis of English local authorities Urban Studies 46 (4): 739-759.

Budaházy Gy. (2013): A földhivatalok méretgazdaságossága a területi szervezet hatékonyságának elemzéséhez. Területi Statisztika 53 (3): 225-236.

Buettner, T. - Schwager, R. - Stegarescu, D. (2004): Agglomeration, population size, and the cost of providing public services: an empirical analysis for German states Public Finance and Management 4 (4): 496-520.

Dollery, B. - Wallis, J. - Akimov, A. (2010): One size does not fit all: The special case of remote small local councils in outback Queensland Local Government Studies 36 (1): 21-42.

Drew, J. - Kortt, M. A. - Dollery, B. (2012): Economies of scale and local government expenditure: evidence from Australia Administration and Society, p. 22. (Online First published on December 17, 2012)

G. Fekete É. - Lados M. - Somlyódiné Pfeil E. - Szoboszlai Zs. (2002): Size of local governments, local democracy and local service delivery in Hungary. In: Swianiewicz, P. (ed.) Consolidation or fragmentation - the scale of local governments in Central and Eastern Europe pp. 31-100., LGIOSI, Budapest.

Gabler, L. R. (1971): Population Size as a Determinant of City Expenditures and Employment - Some Further Evidence Land Economics 47 (2): 130-138.

Hanley, P. F. (2007): Transportation cost charges with statewide school district consolidation Socio-Economic Planning Sciences 41 (2): 163-179.

Hermann Z. - Horváth M. T. - Péteri G. - Ungvári G. (1998): Önkormányzati feladattelepités szempontjai és feltételei Fiscal Decentralization of the Council of Europe - OECD-World Bank, Strasbourg-ParisWashington.

Hirsch, W. Z. (1959): Expenditure implications of metropolitan growth and consolidation Review of Economics and Statistics 41 (3): 232-241.

Hlepas, N-K. (2010): Incomplete Greek territorial consolidation: from the first (1998) to the second (2008-09) wave of reforms Local Government Studies 36 (2): 223-249.

Holcombe, R. G. - Williams, D. W. (2009): Are there economies of scale in municipal government expenditures? Public Finance and Management 9 (3): 416-438.

Hutcheson, J. D. - Prather, J. E. (1979): Economy of scale or bureaucratic entropy? Implications for metropolitan government reorganization Urban Affairs Review 15 (2): 164-182.

Kerekes S. (2002): Méretgazdaságossági és jóléti optimum a környezetvédelmi szolgáltatásokban Közgazdasági Szemle 49(11): 972-985.

Knapp, M. (1982) Economies of scale in local public services: the case of British crematoria Applied Economics 14 (5): 447-453.

Koós B. - Lados M. (2008): Az önkormányzati méretnagyság és a közszolgáltatások méretgazdaságossági kérdései: európai modellek és hazai tapsztalatok. In: Kovács K. - Somlyódiné Pfeil E. (szerk): Függőben. Közszolgáltatás-szervezés a kistelepülések világában. Közigazgatási olvasmányok pp. 45-96. Magyar Közigazgatási Intézet, Budapest.

Kreci, V. - Ymeri, B. (2010): The impact of territorial re-organizational policy interventions in the Republic of Macedonia Local Government Studies 36 (2): 271-290.

Ladd, H. F. (1992): Population growth, density and the costs of providing public services Urban Studies 29 (2): $273-295$. 
Nauges, C. - van der Berg, C. (2008): Economies of density, scale and scope in the water supply and sewerage sector: a study of four developing and transition economies Journal of Regulatory Economics 34 (2): $144-163$

Robertson, F. W. (2007): Economies of scale for large school districts: A national study with local implications The Social Science Journal 44 (4): 620-629.

Saal, D. S. - Arocena, P. - Maziotis, A. - Triebs, T. (2013): Scale and scope economies and the efficient vertical and horizontal configuration of the water industry: a survey of literature Review of Network Economics 12 (1): 93-129.

Swianiewicz, P. (Ed.) (2002): Consolidation or fragmentation - the scale of local governments in Central and Eastern Europe LGI-OSI, Budapest.

Verebélyi I. (1993): Kis- vagy nagyméretü önkormányzatok Magyar Közigazgatás 43 (4): 193-205.

Vrangbaek, K. (2010): Structural reform in Denmark, 2007-2009: Central reform processes in a decentralized environment Local Government Studies 36 (2): 205-221.

Walls, M. - Macauley, M. - Anderson, S. (2005): Private markets, contracts, and government provision. What explains the organization of local waste and recycling markets? Urban Affairs Review 40 (5): 590613.

Wollmann, H. (2010): Territorial local level reforms in the East German regional states (Länder): Phases, patterns, and dynamics Local Government Studies 36 (2): 251-270. 